\title{
Tay-Sachs disease
}

INSERM

\section{Source}

INSERM. (1999). Orphanet: an online rare disease and orphan drug data base. Tay-Sachs disease. ORPHA:845

GM2 gangliosidosis, variant B or Tay-Sachs disease is marked by accumulation of G2 gang liosides due to hexosaminidase A deficiency. 